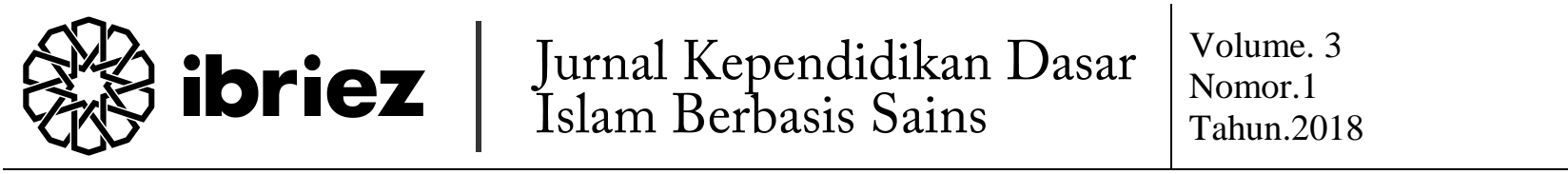

\section{Pembentukan Karakter Islami dalam Pengelolaan Kelas Aktif}

\author{
Amit Dana Ikmah \\ STIT Al Muslihun \\ Surel : amitdanahikmah@gmail.com
}

\begin{abstract}
Abstrak
Pendidikan karakter merupakan pendidikan yang melibatkan aspek pengetahuan, perasaan, dan tindakan. Upaya yang harus dilibatkan dalam pendidikan karakter adalah pihak keluarga, sekolah, lingkungan sekolah, dan juga masyarakat luas. Pembentukan karakter Islami sangat membantu dalam menghadapi kemajuan ilmu pengetahuan dan teknologi yang begitu pesat saat ini. Kegiatan belajar dapat berhasil dengan baik jika proses belajar terjadi secara aktif. Dan proses pembelajaran dapat dikatakan aktif jika semua otak dalam kondisi bekerja. Pengelolaan kelas dapat dilakukan secara aktif dengan adanya peraturan, konsekuensi, dan penghargaan.
\end{abstract}

\section{Kata kunci: karakter Islami, kelas aktif}

\begin{abstract}
Character education is education that involves aspects of knowledge, feelings, and actions. The effort to be involved in character education is family, school, school environment, and also the wider community. The formation of Islamic character is helpful in the face of scientific progress and technology is so rapid at the moment. And the learning process will be active if all the brains are in working condition. Classroom management can be done actively with rules, consequences, and rewards.
\end{abstract}

Keyword : Islamic Character, Active Class 


\section{A. PENDAHULUAN}

Belajar merupakan perubahan kondisi yang diperlihatkan dalam tingkah laku, dimana terjadi perbedaan dari sebelum individu berada dalam situasi belajar dan sesudahnya. Perubahan terjadi akibat adanya suatu pengalaman atau latihan. Dengan belajar manusia akan mendapatkan ilmu. Ilmu adalah perantara bagi manusia untuk mencapai tujuan, ilmu memudahkan manusia untuk menggerakkan pikiran dan melakukan perbuatan sehingga mendapatkan hasil yang diharapkan. Manusia ditakdirkan untuk membutuhkan dan selalu ingin mendapatkan kepuasan atas kebutuhannya.Untuk memenuhi kebutuhan, manusia memerlukan ilmu. ${ }^{1}$ Kebutuhan dan kepuasan manusia cenderung tidak terkendali. Hal ini karena manusia memiliki hawa nafsu. Dengan ilmu manusia dapat mengendalikan hawa nafsunya. Ilmu dapat menjadikan manusia lebih berharkat dan bermartabat. Akan tetapi jika manusia memenuhi kebutuhannya tanpa ilmu, maka dapat menurunkan harkat dan martabatnya. Untuk mendapatkan ilmu, manusia melalui proses yang dinamakan dengan belajar. Selain mendapat ilmu, belajar juga dapat diartikan sebagai proses merubah diri untuk mencapai kedewasaan dan menambah wawasan seseorang.

\section{B. PENGELOLAAN KELAS AKTIF DALAM PROSES PEMBELAJARAN}

Manusia sebagai obyek dan subyek pendidikan memiliki alat yang

\footnotetext{
${ }^{1}$ Riyadhus Shalihin Emka, La Tahzan For Smart Teachers (Menjadi Guru Bahagia Yang Selalu Dikenang Siswa) (Yogyakarta: Araska, 2017), 8.
}

dapat digunakan untuk mencapai kebaikan dan keburukan. Alat yang digunakan untuk mencapai kebaikan adalah hati nurani, akal dan ruh. Sedangkan alat yang dapat digunakan untuk mencapai keburukan adalah hawa nafsu atau syahwat yang berpusat diperut dan hawa nafsu amarah yang berpusat di dada. $^{2}$

Sejak dini anak harus dikenalkan tentang ilmu agama. Allah adalah dzat yang menciptakan dan mengatur alam semesta. Apabila manusia menyadari hakikat tersebut maka ia pasti akan beriman tunduk dan patuh kepada Allah. Mengenal memiki makna berbeda dengan mengetahui, kenal dapat diartikan pasti mengetahui, sedangkan mengetahui belum tentu mengenal. Sebagai makhluk ciptaan Allah SWT tentu kita dituntut untuk lebih mengenalnya. ${ }^{3}$ Orang yang telah mengenal Allah akan menyadari tugas yang harus diemban dalam kehidupan di dunia ini, yaitu beribadah kepadaNya dan mencari keridhaanNya.

Nilai Islam tidak hanya terserap sebagai pengetahuan tetapi menjadi jiwa dan kepribadian. Pemenuhan tuntutan Islam tidak cuma berwujud pada ibadah ritual saja, tetapi pada seluruh aspek kehidupan. $^{4}$ Dan pendidikan harus berupaya mengarahkan manusia agar memiliki keterampilan untuk menuju kebaikan dan menjauhkan diri dari keburukan. Para pakar pendidikan

\footnotetext{
2 Najib Sulhan, Pembangunan Karakter Pada Anak Manajemen Pembelajaran Guru Menuju Sekolah Efektif (Surabaya: Surabaya Intelektual Club, 2010), 10.

3 Tim Satuasa, Buku Pintar Mentoring(Smart, Fun dan Syar'i Panduan Pembinaan Karakter Pelajar) (Jakarta: Yayasan Tunas Bangsa Indonesia, 2016). 4 Tim Satuasa, 248.
} 
seperti Harold G.Shane menyatakan bahwa pendidikan harus didesain untuk merancang kebutuhan masa depan dengan segala konsekuensi yang ditimbulkannya. Pendidikan dalam hal memegang peranan strategis untuk memperkirakan sekaligus mengukur masa depan yang diinginkan dengan berbagai pertimbangan logis. 5

Karakter atau akhlaq juga menjadi tanggung jawab sekolah dalam proses pembentukannya. Di sekolah dasar yang lebih banyak dibangun adalah sikap, kemudian keterampilan dan pengetahuan. Pada jenjang sekolah dasar pembangunan karakter lebih diperkuat. ${ }^{6}$ Dengan demikian pendidikan sebagai suatu investasi harus didesain sesuai dengan kebutuhan pemakainya. Untuk memberi kesempatan agar dapat bertindak secara cerdas dan arif.

$$
\text { Kegiatan belajar dapat saja }
$$

terjadi walaupun tidak ada kegiatan mengajar. Begitu pula sebaliknya, kegiatan mengajar tidak selalu dapat menghasilkan kegiatan belajar. Ketika seorang guru menjelaskan pelajaran di depan kelas maka terjadi kegiatan mengajar, tetapi dalam kegiatan tersebut belum tentu terjadi kegiatan belajar pada setiap siswa. Kegiatan mengajar dikatakan berhasil jika dapat menghasilkan kegiatan belajar pada diri siswa. Jadi, sebenarnya hakekat guru mengajar adalah usaha guru untuk membuat siswa belajar.

\footnotetext{
${ }^{5}$ Mukhtar, Pendidikan Anak Bangsa: Pendidikan Untuk Semua (Nimas Multima, 2002).

${ }^{6}$ Kualita Pendidikan Indonesia, "Modul

Pengelolaan Kelas Aktif" (KPI Surabaya, 2015), 1.
}

Kegiatan belajar hanya dapat
berhasil jika pelajar secara aktif mengalami sendiri proses belajar. Syarat mutlak yang harus dipenuhi agar terjadi kegiatan belajar yaitu terjadinya interaksi antara pembelajar dengan sumber belajar. Pekerjaan mengajar tidak selalu harus diartikan sebagai kegiatan menyajikan materi pelajaran. Meskipun menyajikan materi pelajaran memang merupakan bagian dari kegiatan mengajar, tetapi bukanlah satu-satunya. Masih banyak cara lain yang dapat dilakukan guru untuk membuat siswa belajar. Proses belajar dapat berlangsung secara efektif apabila semua factor internal dan factor eksternal diperhatikan oleh guru. Seorang guru harus dapat mengetahui potensi, kecerdasan, minat, motivasi, gaya belajar, sikap, dan latar belakang social ekonomi dan budaya yang merupakan factor internal pada diri pembelajar. Begitu juga factor eksternal seperti tujuan, materi, strategi, metode, system evaluasi serta cara guru untuk menangani kesulitan siswa dalam belajar. ${ }^{7}$

Guru adalah orang yang mendapat peran penting bagi terjadinya transfer ilmu. Guru merupakan perantara, oleh sebab itu di dalam Islam seorang guru mendapat penghormatan yang jauh lebih tinggi daripada orang yang rajin ibadah sebagaimana banyak dijelaskan dalam Al-Qur'an maupun hadits. ${ }^{8}$ Peran penting yang harus dilakukan oleh guru dalam proses pembelajaran adalah

\footnotetext{
${ }^{7}$ Sulhan, Pembangunan Karakter Pada Anak Manajemen Pembelajaran Guru Menuju Sekolah Efektif, 5.

${ }^{8}$ Sulhan, 15.
} 
mengusahakan agar setiap siswa dapat berinteraksi secara aktif dengan berbagai sumber belajar yang ada. Meskipun guru juga merupakan salah satu sumber belajar bagi siswa, tetapi masih banyak lagi sumber-sumber belajar yang lain yang dapat dimanfaatkan untuk terjadinya proses pembelajaran. Belajar memiliki tujuan untuk mengembangkan potensi peserta didik agar menjadi manusia yang beriman dan bertaqwa kepada Tuhan Yang Maha Esa, berakhlaq mulia, sehat, berilmu, cakap kreatif, mandiri dan menjadi negara yang demokratis serta bertanggung jawab.

Pembelajaran

merupakan

aktivitas dan proses yang sistematis dan sistemik yang terdiri dari beberapa komponen yaitu: guru, kurikulum, anak didik, fasilitas dan administrasi. Masingmasing komponen tidak bersifat parsial (terpisah) atau berjalan sendiri-sendiri, tetapi harus berjalan secara teratur, saling bergantung, dan berkesinambungan. Untuk itu diperlukan rancangan dan pengelolaan belajar yang baik yang dikembangkan dalam rangka mencapai tujuan pembelajaran.

Proses pembelajaran dapat dikatakan aktif jika dalam kondisi semua otaknya bekerja. Potensi otak menjadi dasar dalam menentukan masa depan seseorang perlu mendapat perhatian. Dalam otak anak telah tersedia berbagai ruang sesuai dengan pengalaman masingmasing. Sebagai contoh, ketika anak menerima materi pelajaran baru, maka akan dengan mudah diterima otak manakala ruang yang tersedia di dalam otak memiliki kapasitas yang relevan. ${ }^{9}$

Otak manusia terdiri atas bermilyar-milyar sel aktif. Masing-masing sel dapat membuat jaringan sampai 20.000 sambungan tiap detik. Otak kanan dan otak kiri mempunyai peranan berbeda dan harus diisi sebaik-baiknya. Untuk itu orang tua dan guru memiliki peranan besar dalam melejitkan potensi otak melalui proses pendidikan. Kehebatan otak makhluk hidup ternyata tidak hanya ditentukan jumlah sel otaknya. Tetapi juga oleh kemampuan tiap sel otak yang lain. Otak harus mendapatkan rangsangan dengan memberikan ilmu dan hal-hal kreatif agar pembentukan jaringannya maksimal. Usia 12 tahun atau saat pubertas adalah tahap kecepatan maksimal anak dalam pembentukan jaringan otak, dan tetap berkembang setiap saat namun dengan kecepatan yang semakin lambat. Semakin banyak jaringan yang terbentuk maka anak semakin cerdas dan kreatif. ${ }^{10}$

Anak yang berlarian atau bermain tanpa arah dan tujuan belum dapat dikatakan aktif dalam belajar karena otaknya tidak dalam kondisi bekerja. Otak manusia terbagi menjadi 3 bagian, yaitu otak reptile, otak limbik, otak neukorteks. ${ }^{11}$ Pertama, pada otak reptile perilaku yang ada dalam otak reptil berkaitan dengan insting mempertahankan hidup dan dorongan

\footnotetext{
${ }_{9}^{9}$ Muhammad Yusuf, Memikat Siswa Sejak Menit Pertama (Sidoarjo: MAKS, 2011).

${ }^{10}$ B. L. I. Sutanto Windura, Mind Map Langkah Demi Langkah (Elex Media Komputindo, 2013), 2. 11 "Pemahaman Otak Manusia," Rumah Kemuning, 2 Maret 2018, http://rumahkemuning.com/2011/11/pemaham an-tentang-otak-manusia/otak/.
} 
untuk mengembangkan spesies. Kedua, otak limbic fungsinya bersifat emosional dan kognitif; yaitu ia menyimpan perasaan manusia, pengalaman yang menyenangkan, memori, dan kemampuan belajar manusia. Selain itu, sistem ini juga mengendalikan manusia, seperti pola tidur, lapar, haus, tekanan darah, detak jantung, gairah seksual, temperatur tubuh, metabolisme dan sistem kekebalan. Ketiga, otak neokorteks bagian otak ini merupakan tempat bersemayamnya kecerdasan manusia inilah yang mengatur pesan-pesan yang diterima melalui penglihatan, pendengaran, dan sensasi tubuh manusia. Proses yang berasal dari pengaturan ini adalah penalaran, berpikir secara intelektual, pembuatan keputusan, perilaku waras, bahasa, kendali motorik sadar dan ideasi (penciptaan gagasan) nonverbal. Dalam neokortekslah semua kecerdasan yang lebih tinggi berada, yang membuat manusia unik sebagai spesies. Informasi yang diterima dikelola oleh panca indera dan selanjutnya dilanjutkan pada otak, ketika proses belajar mengajar berlangsung semua informasi diterima melalui ingatan panca indera (ingatan sensoris) terutama pendengaran, ketika otak tidak membutuhkan maka tidak dikirimkan ke tingkatan selanjutnya dan segera dilupakan, oleh sebab itu siswa dituntut untuk lebih aktif dan guru sebagai fasilitator. Jika siswa banyak melakukan praktik atau belajar langsung di dunia nyata atau dapat dengan pengulangan yang terus menerus dapat menjadi ingatan jangka panjang. Kegiatan pengelolaan informasi yang berlangsung di dalam otak akan menentukan perubahan perilaku seseorang. Bukan sebaliknya jumlah informasi atau stimulus yang mengubah perilaku. Demikian pula kinerja seseorang yang diperoleh dari hasil belajar tidak tergantung pada jenis dan cara pemberian stimulus, melainkan lebih ditentukan oleh sejauh mana seseorang mampu mengelola informasi sehingga dapat disimpan dan digunakan untuk merespon stimulus yang berada di sekelilingnya.

Terdapat dua faktor yang mempengaruhi otak dalam membentuk ingatan jangka panjang, yaitu arti atau makna informasi dan keterkaitan informasi dengan diri kita. Emosi positif dapat memainkan peranan penting dalam peningkatan pembelajaran. Apa pun yang dilakukan dengan melibatkan emosi positif siswa, maka akan berpengaruh kepada peningkatan motivasi dan minat mereka secara alami. Di mana peningkatan tersebut mempengaruhi sistem untuk menghasilkan ingatan yang lebih kuat. Seringkali emosi dapat mengganggu proses pembelajaran. Bertahan bukan hanya bersangkutan dengan binatang buas. Situasi pembelajaran dan social juga seringkali merupakan pertempuran untuk bertahan hidup. Emosi berpengaruh besar pada kualitas dan kuantitas belajar .

Emosi yang positif dapat mempercepat proses belajar dan mencapai hasil belajar yang lebih baik, sebaliknya emosi yang negatif dapat memperlambat belajar atau bahkan menghentikannya sama sekali. Guru memiliki kemampuan mengolah emosi secara lebih baik dan canggih. Jika 
berbicara dengan anak dengan cara jongkok dengan begitu wajah sejajar dengan anak, mata berada tepat didepan anak sehingga mudah mengendalikan emosi anak daripada bicara sambil berdiri. ${ }^{12}$ Sikap sejajar secara fisik antara guru dengan murid akan mempengaruhi pandangan guru secara psikis. Dengan berjongkok akan mudah menahan amarah. Sikap ini sesuai dengan anjuran Rasulullah SAW agar segera duduk jika sedang marah, jika masih marah dianjurkan untuk berbaring, jika sudah berbaring masih juga marah berwudhu menjadi solusi mujarab penghilang marah.

Pembelajaran yang berhasil haruslah dimulai dengan menciptakan emosi yang positif pada diri pelajar. Jika siswa mengalami emosi positif, mereka dapat menggunakan neokorteks untuk tugas-tugas belajar. Untuk menciptakan emosi positif pada diri siswa dapat dilakukan dengan berbagai cara, diantaranya adalah dengan menciptakan lingkungan belajar yang menyenangkan. Lingkungan yang dimaksud di sini mencakup lingkungan fisik dan lingkungan psikologis. Lingkungan fisik mencakup penataan ruang kelas dan penataan alat bantu belajar, sedang lingkungan psikologis mencakup penggunaan musik untuk meningkatkan hasil belajar. Penataan ruang kelas, seperti penataan tempat duduk, pajangan, dan penyediaan wewangian, memainkan peranan penting dalam menciptakan emosi positif dalam belajar. Bayangkan

\footnotetext{
${ }^{12}$ Abdullah Munir, Spiritual Teaching: Agar Guru Mencintai Pekerjaan dan anak didiknya (Yogyakarta: Pustaka Insan Madani, 2006).
}

jika siswa masuk ke ruang kelas yang pengap dan bau dengan dinding yang kosong atau pajangan, serta susunan bangku yang membosankan, maka sulit diharapkan mereka dapat mencapai hasil belajar yang optimal.

Kecerdasan emosi merupakan kemampuan mengenali emosi diri sendiri, mengelola, mengekspresikannya dengan tepat, memotivasi diri sendiri, mengenali orang lain, dan membina hubungan dengan orang lain. Dengan demikian, kecerdasan emosi adalah kemampuan seseorang dalam mengelola emosinya secara sehat terutama dalam berhubungan dengan orang lain. Unsur terpenting dalam kecerdasan emosi adalah empati dan kontrol diri. Empati berarti dapat merasakan apa yang sedang dirasakan orang lain, terutama bila orang lain dalam keadaan malang. Sedangkan kontrol diri adalah kemampuan untuk mengendalikan emosi diri sehingga tidak menganggu hubungan dan komunikasi dengan orang lain.

Kecerdasan emosi perlu ditumbuhkan sejak usia dini melalui naskah emosi yang sehat agar dapat diinternalisasi anak sejak dini dan dibawa terus dalam berinteraksi dengan orang lain bila ia dewasa kelak. Ada beberapa cara yang dapat dilakukan baik oleh orang tua maupun guru dalam rangka mengajarkan naskah emosi yang sehat pada anak, diantaranya: ajarkan nilai-nilai budaya setempat dimana anak hidup; kenali dulu emosi-emosi anak yang menonjol, baru ajarkan anak untuk mengenali emosi-emosi itu; berilah nama dari emosi anak yang menonjol. Misalnya: anak sering menangis bila apa yang 
dimaunya tidak segera dituruti; katakan padanya bahwa ia sedang marah, dan kita tahu bahwa dia marah kehendaknya tidak terkabul; kenalkan anak tentang emosi anak dengan cara lain selain kata-kata; ekspresikan emosi anda dengan bahasa tubuh atau dengan ekspresi wajah. Misalnya rangkullah dia bila sedang duduk berdua, cium dia bila anda sedang berbahagia, dekap ia bila sedang pedih, cemberutkan wajah bila kita tidak berkenan dengan perilakunya , dan sebagainya; buatlah disiplin yang konsisten pada diri kita agar anak belajar menghormati otoritas.

Menghormati otoritas sangat diperlukan untuk menghindarkan ia dari tindakan yang tidak benar; ajarkan pada anak ekspresi emosi yang dapat diterima oleh lingkungan. Misalnya: perasaan sedih karena tidak dapat membeli sesuatu yang tidak boleh diekspresikan dengan menangis meraung-raung di toko, bahwa bila ada tetangga meninggal jangan menghidupkan radio keras-keras, bila sedang berbahagia jangan tertawa terbahak-bahak sampai langit-langit mulut terlihat lawan bicara; tunjukkan perilaku kita sendiri yang ditiru oleh anak secara langsung. Misalnya memberi sedekah pada pengemis, mengajak ke panti asuhan; pupuk rasa empati dengan memelihara ternak atau hewan peliharaan lain. Ajak anak mengamati tingkah laku hewan itu dan mendiskusikan kira-kira hewan itu sedang merasakan apa. ${ }^{13}$ Pada situasi

\footnotetext{
${ }^{13}$ Amanah, "Civic education and education technology: PENGARUH EMOSI PADA BELAJAR," Civic education and education technology (blog), 2 Oktober 2011,
}

emosi, otak merasakan situasi yang mengancam, tanggapan stres (melawan atau lari) akan dimulai lebih menonjol dibandingkan pikiran. Bagian dari otak untuk berfikir/berakal akan berkurang tingkat efisiensinya dan seringkali mengganggu proses pembelajaran. Lingkungan harus aman, baik secara fisik maupun kejiwaan agar proses pembelajaran yang terbaik dapat terjadi.

Dalam proses pembelajaran, siswa diharapkan untuk aktif dalam hal bertanya, mengemukakan pendapatnya, mengeksplor pengalamannya dan kegiatan kelas lainnya. Perkembangan teori-teori tentang bagaimana siswa belajar dan berkembang, bermacammacam paket atau media belajar, dan metode-metode belajar baru, telah mendorong para pendidik untuk mencari pendekatan baru dalam mengembangkan sistem dan disain instruksional. Pendekatan baru ini didasarkan atas kenyataan bahwa kegiatan belajar mengajar merupakan suatu hal yang sangat kompleks, terdiri atas banyak komponen yang satu sama lain harus bekerja bersama secara baik untuk mencapai hasil yang sebaik-baiknya.

Mengajar merupakan kegiatan menciptakan suasana yang mengembangkan inisiatif dan tanggung jawab belajar si pembelajar, sehingga berkeinginan terus untuk belajar selama hidupnya dan tidak tergantung pada guru/orang lain. Masalah perilaku penting untuk ditekankan dalam pembelajaran supaya kegiatan pembelajaran juga dapat berlangsung

http://homeamanah.blogspot.com/2011/10/pen garuh-emosi-pada-belajar.html. 
dengan baik sehingga mencapai tujuan pembelajaran yang diharapkan sesuai anjuran dalam Al-Qur'an dan Hadits .

\section{PENDIDIKAN SEBAGAI PERANTARA DALAM PEMBENTUKAN KARAKTER}

Membentuk siswa yang berkarakter bukan suatu upaya mudah dan cepat. Hal tersebut memerlukan upaya terus menerus dan refleksi mendalam untuk membuat rentetan keputusan moral yang harus ditindak lanjuti dengan aksi nyata, sehingga menjadi hal yang praktis dan reflektif. Diperlukan sejumlah waktu untuk membuat semua itu menjadi kebiasaan dan membentuk watak atau tabiat seseorang. Selain itu pencanangan pendidikan karakter tentunya dimaksudkan untuk menjadi salah satu jawaban terhadap beragam persoalan bangsa yang saat ini banyak dilihat, didengar, dan dirasakan, yang mana banyak persoalan muncul yang diindentifikasi bersumber dari gagalnya pendidikan dalam menyuntikkan nilai nilai moral terhadap peserta didiknya. Hal ini tentunya sangat tepat, karena tujuan pendidikan bukan hanya melahirkan insan yang cerdas, namun juga menciptakan insan yang berkarakter kuat.

Pendidikan karakter merupakan upaya yang harus melibatkan semua kepentingan dalam pendidikan, baik pihak keluarga, sekolah, lingkungan sekolah, dan juga masyarakat luas. Oleh karena itu, langkah awal yang perlu dilakukan adalah membangun kembali kemitraan dan jejaring pendidikan yang kelihatannya mulai terputus antara lingkungan sekolah yaitu guru, keluarga, dan masyarakat. Pembentukan dan pendidikan karakter tidak akan berhasil selama tidak ada kesinambungan dan keharmonisan antara lingkungan pendidikan. Dengan demikian, rumah tangga dan keluarga sebagai lingkungan pembentukan dan pendidikan karakter pertama dan utama harus lebih diberdayakan yang kemudian didukung oleh lingkungan dan kondisi pembelajaran di sekolah yang memperkuat proses pembentukan tersebut.

Karakter dapat diartikan sebagai cara pola berpikir dan berperilaku seseorang yang merupakan mencerminkan dirinya baik secara individu maupun secara bersama sama, baik dalam lingkup keluarga, masyarakat dan bernegara. Karakter atau akhlaq juga menjadi tanggung jawab sekolah dalam proses pembentukannya. Di sekolah dasar yang lebih banyak dibangun adalah sikap, kemudian keterampilan dan pengetahuan. Pada jenjang sekolah dasar pembangunan karakter lebih diperkuat. ${ }^{14}$ Untuk lebih singkatnya karakter merupakan pembawaaan seseorang yang didapatkan sejak kecil. Karakter sangat erat hubungannnya dengan nilai nilai agama, kejiwaan, akhlak dan budi pekerti seseorang yang membedakan terhadap yang lainnya. Sejalan dengan perkembangan jaman juga di ikuti dengan pergeseran moral sebagai karakter/budaya negara timur, baik yang datang dari negara kita sendiri

\footnotetext{
14 Kualita Pendidikan Indonesia, "Modul Pengelolaan Kelas Aktif," 1.
} 
maupun budaya yang dibawa dari negara asing.

Lingkungan memiliki pengaruh yang sangat besar terhadap proses perkembangan kehidupan. Pengaruh lingkungan dan budaya di luar rumah sangatlah mengkawatirkan bagi perkembangan anak. Sikap dan perilaku keluarga harus dapat dijadikan panutan oleh anak. Anak selalu menirukan apa yang dilihat dan di dengarnya. Perilaku dan kebiasaan dalam keluarga menjadi pusat perhatian anak.

Orang tua memiliki pengaruh yang sangat besar dalam keberhasilan pendidikan karakter anak dalam lingkungan keluarga, baik secara psikis seperti pemenuhan kebutuhan akan makan dan mimum juga kebutuhan kasih sayang serta rasa aman dari gangguan apapun terhadap anak. Konsep manusia menurut Islam seperti yang tertuliskan di dalam Al-Qur'an adalah sebagai makhluk segala karakter. Berbagai karakter ada pada diri manusia. Ada yang memiliki karakter baik adapula yang jahat. Karakter terbentuk dalam proses perkembangan kehidupan. Manusia dilahirkan dengan membawa fitrah yakni kecenderungan untuk berbuat baik. ${ }^{15}$

Anak usia dini sangat sensitif terhadap apa yang ia lihat, karena anak lebih sering bersama orang tua tentu akan meniru apa yang dilakukan pihak orang tua. Bila orang tua dalam mendidik atau berperilaku secara keras, lembut, demokrasi, otoriter, dan lain sebagainya

15 Hernowo, Menjadi Guru yang Mau dan Mampu Mengajar Secara Kreatif (Jakarta: Mizan, 2006), 26. kemungkinan besar anak tersebut akan merekam- artikel tentang pendidikan.

Disamping itu, tidak kalah pentingnya pendidikan di masyarakat. Lingkungan masyarakat sangat mempengaruhi karakter seseorang. Lingkungan masyarakat luas sangat berpengaruh terhadap keberhasilan penanaman nilai-nilai etika, estetika untuk pembentukan karakter. Sistem nilai yang dianut oleh masyarakat dapat mempengaruhi sikap dan cara pandang masyarakat secara keseluruhan. Jika sistem nilai dan pandangan mereka terbatas, maka upaya dan ambisinya terbatas pada hal yang sama.

Dewasa ini, krisis moral semakin meningkat. Penggunaan narkoba, kekerasan yang terjadi dimana mana, dan rasa hormat terhadap orang lebih tua yang semakin menurun sebagai bukti penurunan moral yang terjadi. Hal ini terlepas dari pergaulan serta pendidikan yang ditanamkan pada dirinya di usia dini. Di usia 6 bulan sampai dengan 1 tahun pertama merupakan usia yang paling berpengaruh dalam perkembangan anak hingga tumbuh remaja. Usia 6 bulan sampai dengan satu tahun merupakan usia emas pada usia ini sangat menentukan ketika anak tumbuh dewasa dimana bila salah dalam mendidik pada usia tersebut kemungkinan besar anak tersebut juga salah, sebaiknya diberikan pengenalan terhadap pendidikan karakter pada usia dini.

Para pakar pendidikan seperti Harold G.shane, menyatakan bahwa pendidikan harus didesain untuk merancang kebutuhan masa depan dengan segala konsekuensi yang 
ditimbulkannya. Pendidikan dalam hal memegang peranan strategis untuk memperkirakan sekaligus mengukur masa depan yang diinginkan dengan berbagai pertimbangan logis. ${ }^{16}$ Dengan demikian pendidikan sebagai suatu investasi harus didesain sesuai dengan kebutuhan pemakainya. Untuk memberi kesempatan agar dapat bertindak secara cerdas dan arif.

Dalam membangun karakter anak kita harus menanamkan nilai nilai positive seperti: Taat kepada agama/religius, jujur baik dalam perkataan maupun dalam perbuatan, jangan sesekali memperlihatkan sikap curang terhadap anak karena dia akan merekam dan akan melakukan hal yang sama, bertanggung jawab dalam segala hal yang ia lakukan, rasa percaya diri perlu ditanamkan terhadap anak agar saat ia remaja tidak suka minder yang membuat ia tertinggal dengan sebayanya, mandiri, demokratis, peduli terhadap sesama, hormat dan sopan kepada orang tua serta orang lain yang lebih tua, disiplin disegala hal, pekerja keras dan lain sebagainya yang merupakan sikap positif.

Membentuk karakter bukanlah perkara yang mudah dan diperlukan aksi nyata karena karakter memang tidak dapat diwariskan atau diturunkan begitu saja melainkan membangun secara berkesinambungan dan berkelanjutan melalui pola pikir dan aksi nyata. Banyak hal yang dapat dilakukan untuk merealisasikan itu diantaranya dengan pengenalan dan menanamkan nilai - nilai positive diatas. Meski kita telah berupaya

16 Mukhtar, Pendidikan anak bangsa, 127. semaksimal mungkin tetapi seringkali berseberangan dengan apa yang harapkan. Umumnya pendidikan karakter anak dipengaruhi tiga factor, yaitu keluarga, lingkungan sekolah, tempat bermain atau masyarakat luas. Pembentukan karakter tidak akan terealisasi bila ketiganya tidak ada kesinambungan serta keharmonisan. Dengan demikian, lingkungan keluarga merupakan faktor utama dalam pembentukan karakter yang selanjutnya lingkungan sekolah melalui pembelajaran maupun materi materi terapan untuk memperkuat siklus yang akan dibentuk tadi. Di sisi lain lingkungan merupakan factor yang tidak kalah penting untuk keberhasilan dalam membentuk pola anak.

Banyak teori yang bermunculan untuk mewujudkan karakter anak yang berkualitas dan menjanjikan untuk menjawab persoalan bangsa ini khususnya tentang moral. Namun pada kenyataannya seringkali tidak sesuai dengan harapan. Mengganggu kelas merupakan perilaku tidak terkendali yang aktif, sedangkan tidak memperhatikan pelajaran dan tidak menyelesaikan tugas adalah perilaku tidak terkendali yang pasif. Membantu setiap siswa untuk dapat mengawasi perilakunya sendiri adalah suatu cara agar mereka dapat mengendalikan perilakunya sendiri.17 Untuk itu diperlukan sebuah upaya atau progaram yang terukur untuk menilai

\footnotetext{
17 Pat Hollingsworth dan Gina Lewis, Pembelajaran Aktif Meningkatkan Keasyikan Kegiatan di Kelas, trans. oleh Dwi Wulandari (Jakarta: Indeks, 2008), 127.
} 
berhasil tidaknya pendidikan yang diterapkan.

Pendidikan karakter melalui sekolah, tidak semata - mata pembelajaran pengetahuan semata, tetapi lebih dari itu, yaitu penanaman moral, nilai - nilai etika, estetika, dan budi pekerti yang luhur. Selain itu karakter yang harus dimiliki siswa diantaranya yaitu kerja sama, disiplin, taat, dan tanggung jawab. Dan yang terpenting adalah setiap elemen mempraktikkan dan melakukan dengan disiplin. Proses belajar mengajar berkarakter memiliki karakteristik megarahkan siswa pada hasil belajar yang produktif, melibatkan siswa secara aktif, merangsang siswa berfikir kritis dan kreatif, strategi pembelajaran dengan cara yang efektif, suasana pembelajaran gembira dan menyenangkan. Dalam hal ini peran guru sangat besar demi terwujudnya hal-hal tersebut.

Guru membentuk karakter anak dengan memberikan keteladanan, cara berbicara yang baik, toleransi dan berbagai hal yang bersifat positif sesuai yang diajarkan di dalam Al-Qur'an dan hadist. Pendidikan dasar merupakan pondasi utama bagi tumbuh kembang generasi bangsa. Penyelenggaraan pendidikan karakter menjadi satu hal yang mutlak dilakukan dijenjang manapun, khususnya di jenjang pendidikan dasar. Di dunia tidak ada anak nakal karena setiap anak memiliki keunikan dan latar belakang yang berbeda. Mereka mengeksplor kemampuannya dengan cara mereka masing-masing.
Seorang pendidik harus dapat memahami karakteristik dan kemampuan siswa yang dihadapi. Terdapat 3 jenis kemampuan yaitu auditori, visual, dan kinestetik. Dalam proses belajar ketiga kemampuan yang dimiliki oleh masingmasing siswa tersebut tidak dapat disamakan. Media dan metode yang digunakan pun harus berbeda karena mereka menerima segala yang kita sampaikan dengan cara yang berbeda.

\section{PERAN PERATURAN, KONSEKUENSI DAN PENGHARGAAN TERHADAP PEMBENTUKAN KARAKTER}

Karakter islami sangat penting untuk ditumbuhkah sejak usia dini, tidak hanya dalam pengelolaan kelas tapi dalam keluarga juga perlu ditumbuhkan. Menumbuhkan keislaman dalam keluarga dapat dilakukan dengan membudayakan sholat tepat waktu, membiasakan anak ikut berperan dalam kegiatan beribadah.

Adapun beberapa senjata ampuh untuk menuju pendidikan yang sukses adalah pertama dengan akhlaq. Segala tingkah laku, sopan santun guru akan menjadi panutan muridnya. Diantaranya guru dan siswa harus ada secure attachment, apabila anak berhasil membangun secure attachment, maka dia akan memiliki ruang yang aman, tempat anak belajar memahami dan memaknai dunia, tempat anak selalu dapat kembali dan disambut dengan baik dan direspon kebutuhannya, tempat anak mendapatkan nutrisi fisik dan psikologis. Pola yang terbentuk dari masa kecil akan mempengaruhi kompetensi emosi, social dan kognitif anak serta hubungan 
interpersonal dimasa yang akan datang. Semakin aman pola attachment yang terbentuk, semakin besar kemungkinan akan mengembangkan hubungan positif dengan orang lain sehingga dapat melahirkan anak yang memiliki karakter yang islami juga.

Kedua dengan minat dan semangat belajar. Guru tidak perlu banyak mengajar, justru lebih perlu banyak menggagas tentang beragam bintang prestasi di langit yang perlu setiap siswa gapai. Membangun hubungan positif dapat mempermudah kita untuk mengendalikan anak didik kita. Hubungan positif mengacu pada kebutuhan untuk merasakan koneksi hubungan dengan orang lain disekitarnya. Termasuk kebutuhan untuk dicintai dan mencintai, peduli dan dipedulikan, merasakan kedekatan, hubungan interpersonal yang aman dan dilandasi rasa percaya, merasa diterima dan menjadi bagian dari kelompok. Hubungan positif ada sejak manusia lahir dan termasuk salah satu nutrisi psikologis yang esensial bagi proses perkembangan dan kesehatan jiwa setiap individu. Anakanak yang memiliki hubungan positif memiliki motivasi dan keberanian untuk mengeksplorasi dunia di sekitarnya, percaya bahwa akan ada sosok aman yang mendukung dan merespon kebutuhannya. Ketika mereka sudah merasa aman dan nyaman maka kita mudah mengendalikannya dan tujuan dari proses pembelajaran pun akan tercapai sesuai yang diharapkan pengajar.

Ketiga dengan pengasuhan dan pengayoman. Anak percaya bahwa orang tua atau figur penggantinya akan hadir, merespon dan membantunya ketika dia mengalami kemalangan atau situasi yang menakutkan. Pola ini terbentuk dari interaksi dengan orang tua yang siap hadir dalam hidup anak, sensitive membaca sinyal kebutuhannya dan merespon dengan cinta ketika dia sedang dalam masalah, membutuhkan perlindungan dan kenyamanan. Guru harus benar-benar pengganti orang tua yang menerapkan asah, asih, asuh, namun sekali lagi bukan dalam arti mengajar tapi mendidik. Dalam mengasuh anak di sekolah harus ada kerjasama antara guru dan orang tua sehingga nanti dapat memperoleh hasil yang maksimal. Pada anak usia dini ucapan guru lebih diperhatikan dan dipercaya daripada ucapan orang tuanya.

Adanya budaya religius diharapkan akan sangat membekas dan mengakar dalam diri anak. Terlebih dengan memberikan contoh-contyang tidak ingin dilakukan oleh siswa. Membuat oh tentang perilaku positif yang diharapkan akan dilakukan oleh siswa dan menghindari perilaku negatif yang dapat ditiru oleh siswa. Peraturan yang disepakati semua pihak dapat menumbuhkan suasana yang kondusif di dalam pengelolaan kelas. Peraturan seharusnya dinyatakan secara positif , singkat, dapat dipahami, dan dapat dilaksanakan. Adapun jenis macam peraturan dalam pengelolaan kelas ada dua, yaitu aturan formal dan aturan non formal. Aturan formal merupakan kesepakatan yang dilakukan sebuah kelompok untuk mencapai sebuah nilai yang dijunjung tinggi oleh kelompok tersebut. Misal aturan kelas, aturan di 
ruang makan. Sedangkan aturan non formal merupakan aturan yang berkaitan dengan penggunaan alat yang berlaku sepanjang tahun bahkan sepanjang hayat, misalkan cara menggunakan gunting, cara bermain sebuah alat.

Untuk menjaga peraturan yang sudah ada, terdapat beberapa hal yang perlu dilakukan misalkan mengingatkan secara verbal, mengingatkan secara non verbal (tanda). Anak juga harus dididik untuk belajar disiplin menghargai waktu. Disiplin merupakan pengaruh yang dirancang untuk membantu anak mampu menghadapi lingkungannya, disiplin tumbuh dari kebutuhan menjaga keseimbangan antara kecenderungan dan keinginan individu untuk berbuat agar memperoleh sesuatu, dengan pembatasan atau peraturan yang diperlukan oleh lingkungan terhadap dirinya. ${ }^{18}$ Ketaatan terhadap peraturan tersebut tidak dapat diperoleh dengan sendirinya. Orang tidak begitu saja taat terhadap sesuatu. Disiplin pribadi untuk taqwa terhadap tuhan tidak siap jadi, meskipun ia sudah dilatih untuk beribadah.

Sebagai pendidik, guru harus menguasai cara mengatur kelas dan menyusun pelajaran agar mengurangi perilaku yang tidak benar, cara yang paling efektif bagi guru untuk berinteraksi dengan siswa, cara untuk mengembangkan dan menerapkan kegiatan rutin dan prosedur yang membantu untuk menciptakan suatu lingkungan belajar yang aman dan menunjang keberhasilan. Ketika ada

\footnotetext{
18 Conny R. Semiawan, Penerapan Pembelajaran
} pada Anak (Jakarta: Indeks, 2009), 28. pelanggaran harus ada yang terjadi yaitu konsekuensi.

Konsekuensi logis adalah akibat yang diterima dari sebab perilaku yang telah dilakukan oleh pelaku. Agar dapat dipandang sebagai konsekuensi logis, peserta didik harus memandang konsekuensi itu sebagai sesuatu yang wajar. Konsekuensi logis sebagai realitas tertib sosial yang berkaitan langsung dengan perilaku yang menyimpang. Tidak termasuk unsur pertimbangan moral, dan hanya menyangkut apa yang akan terjadi dikemudian hari. ${ }^{19}$ Sebelum menggunakan konsekuensi logis, mulamula harus menjelaskan secara jelas perilaku-perilaku apa yang diharapkan untuk dilakukan oleh peserta didik serta alasan-alasan melakukannya, kemudian menjelaskan pula hubungannya dengan konsekuensi logis jika peserta didik tidak memenuhi harapan tersebut. ${ }^{20}$ Guru disarankan dapat menunjukkan secara tepat perilaku yang salah dengan cara bijaksana dan alami, sehingga membantu peserta didik dalam mengatasinya, kemudian memanfaatkan akibatakibatnya dengan menggunakan konsekuensi logis, agar perilaku yang tidak diharapkan tidak terulang lagi.

$$
\text { Konsekuensi logis terjadi }
$$

berdasarkan jalannya kejadian yang muncul secara alami/wajar, tanpa adanya campur tangan orang dewasa yang terlalu besar. Guru dan orang tua harus

19 "God Bless si Pembunuh Karakter," diakses 11 September 2018,

http://belajarinfo333.blogspot.com/2014/11/pe mbunuhan-karakter-character.html.

${ }^{20}$ Michael S. Josephson, Val J. Peter, dan Tom Dowd, Menumbuhkan 6 Sikap Remaja Idaman: Panduan bagi Orangtua (Bandung: Mizan, 2003), 28. 
menghindari untuk mengambil alih rasa tanggung jawab yang seharusnya dipikul oleh anak, dan jangan menanggung akibat-akibat yang timbul dari tindakantindakannya. Apabila dalam suasana yang penuh kejengkelan memberikan ancaman dengan konsekuensi logis, maka dalam hal ini konsekuensi logis tadi digunakan sebagai alat untuk menghukum. Konsekuensi logis hanya diberikan setelah strategi penegakan peraturan sudah dijalankan dengan baik.

Penghargaan adalah sebuah bentuk apresiasi kepada suatu prestasi tertentu. Penghargaan merupakan rangsangan untuk meningkatkan frekuensi suatu perbuatan yang mendahuluinya. ${ }^{21}$ Suatu penghargaan merupakan suatu obyek atau peristiwa yang diinginkan, dapat dicapai dengan memenuhi beberapa persyaratan yang jika dilakukan maka sesorang akan mendapatkan hal tersebut.

\section{Penghargaan}

berhasil

menjadikan seseorang melakukan sesuatu untuk jangka waktu pendek, namun pengaruh jangka panjangnya dapat sangat negatif. Penggunaan penghargaan berulang-ulang kali dapat menjadikan seseorang tergantung pada penghargaan dan menghilangkan motivasi dari dalam diri mereka. Jika orang selalu mendapatkan penghargaan ketika melakukan hal yang benar, maka mereka akan selalu berharap mendapatkan penghargaan ketika melakukanya lagi.

Penghargaan dapat merusak hubungan. Ketika seseorang diberi penghargaan atau dipuji, yang lain dapat merasa iri dan mereka akan membenci orang tersebut. Jika seorang guru terlihat sebagai seseorang yang memberikan penghargaan pada siswa-siswanya maka para siswa mungkin akan termotivasi hanya untuk menyenangkan guru tersebut. Mereka tidak akan selalu jujur dengan guru tersebut. Penghargaan menciptakan persaingan di dalam kelas dan persaingan menciptakan kecemasan. Mereka yang percaya bahwa mereka tidak akan mempunyai kesempatan untuk mendapatkan suatu penghargaan akan berhenti mencoba.

Tujuan pembelajaran di dalam kelas adalah untuk menciptakan suatu hubungan yang terbuka dan saling percaya antara guru dan siswa. Tetapi jika guru atau orang tua berada dalam posisi menghakimi dan penentu untuk menghargai atau tidak, maka hampir dapat dipastikan sikap terbuka siswa dalam meminta bantuan akan berkurang. Hal ini akan memberikan efek terhadap tugas-tugas sekolah yang mereka emban. Mereka merasa takut untuk meminta bantuan dalam menyelesaikan tugastugas sekolah.

Anak sangat membutuhkan pujian atau penghargaan. Dapat dengan kata-kata, acungan jempol, senyuman atau kata yang memotivasi. Pujian harus dilakukan secara proporsional dan kondisional. Pujian harus proporsional supaya bernilai bagi anak. Semakin sering dipuji maka nilainya akan berkurang bagi anak. Pujian juga harus diberikan secara proporsional agar anak tidak merasa

21 "God Bless si Pembunuh Karakter." 
sombong. ${ }^{22}$ Penghargaan dan hukuman sering digunakan saat ada suatu masalah. Jika kita menggunakan penghargaan dan hukuman untuk memecahkan masalah, kita tidak harus melihat sebab dari masalah tersebut. Misalnya, seorang anak sedang menangis, atau sedang melamun atau datang terlambat ke kelas. Kita pertama kali harus melihat alasan-alasan apa yang menjadi penyebabnya jika kita ingin menyelesaikan masalah tersebut untuk waktu jangka panjang.

Penghargaan tidak mendorong pengambilan resiko. Ketika kita bekerja untuk suatu penghargaan, kita akan melakukan tepat seperti yang dibutuhkan untuk mendapatkan penghargaan dan tidak lebih. Kita tidak lagi mencari kemungkinan-kemungkinan; kita mencari cara yang termudah untuk mencapai sasaran. Tujuan kita adalah untuk mendapatkan penghargaan bukan untuk meraih kesuksesan atas suatu tugas. Perilaku kreatif tidak mungkin terjadi saat kita bekerja untuk penghargaan. Pemantapan hanya dapat mendorong pengulangan dari apa yang telah ia lakukan di waktu lalu, tidak akan berhasil untuk mendapatkan tanggapan kreatif yang berkelanjutan. Secara tidak sadar sebenarnya penghargaan dapat membunuh minat. Jika penghargaan digunakan, ini sama saja dengan memberitahu orang tersebut bahwa kegiatan ini tidak layak dilakukan.

\section{E. KESIMPULAN}

${ }^{22}$ Muhammad Sajirun, Membentuk karakter Islami anak usia dini (Surakarta: Era Adicitra Intermedia, 2012), 54.
Pembelajaran aktif menuntut anak untuk mengalami sendiri proses belajar. Proses pembelajaran didukung oleh adanya peraturan, konsekuensi, serta penghargaan. Penerapan ketiga hal tersebut akan menjadikan kelas semakin hidup sehingga siswa aktif dalam kegiatan pembelajaran. Suasana pembelajaran yang aktif akan membentuk karakter siswa. Pembentukan karakter positif harus dilaksanakan secara berkesinambungan dan berkelanjutan melalui pola pikir dan aksi nyata. Dengan begitu karakter anak dapat terbentuk sesuai dengan harapan.

\section{F. DAFTAR PUSTAKA}

Amanah. "Civic education and education technology: PENGARUH EMOSI PADA BELAJAR." Civic education and education technology (blog), 2 Oktober 2011.

http://homeamanah.blogspot.com /2011/10/pengaruh-emosi-padabelajar.html.

Emka, Riyadhus Shalihin. La Tahzan For Smart Teachers (Menjadi Guru Bahagia Yang Selalu Dikenang Siswa). Yogyakarta: Araska, 2017.

"God Bless si Pembunuh Karakter." Diakses 11 September 2018. http://belajarinfo333.blogspot.co m/2014/11/pembunuhankarakter-character.html.

Hernowo. Menjadi Guru yang Mau dan Mampu Mengajar Secara Kreatif. Jakarta: Mizan, 2006.

Hollingsworth, Pat, dan Gina Lewis. Pembelajaran Aktif Meningkatkan Keasyikan Kegiatan di Kelas. Diterjemahkan oleh Dwi Wulandari. Jakarta: Indeks, 2008. Josephson, Michael S., Val J. Peter, dan Tom Dowd. Menumbuhkan 6 Sikap 
Remaja Idaman: Panduan bagi Orangtua. Bandung: Mizan, 2003.

Kualita Pendidikan Indonesia. "Modul

Pengelolaan Kelas Aktif." KPI

Surabaya, 2015.

Mukhtar. Pendidikan Anak Bangsa:

Pendidikan Untuk Semua. Nimas

Multima, 2002.

Munir, Abdullah. Spiritual Teaching: Agar

Guru Mencintai Pekerjaan dan

anak didiknya. Yogyakarta:

Pustaka Insan Madani, 2006.

"Pemahaman Otak Manusia." Rumah

Kemuning, 2 Maret 2018.

http://rumahkemuning.com/2011

/11/pemahaman-tentang-otakmanusia/otak/.

Sajirun, Muhammad. Membentuk karakter Islami anak usia dini. Surakarta:

Era Adicitra Intermedia, 2012.

Semiawan, Conny R. Penerapan

Pembelajaran pada Anak. Jakarta:

Indeks, 2009.

Sulhan, Najib. Pembangunan Karakter

Pada Anak Manajemen

Pembelajaran Guru Menuju Sekolah

Efektif. Surabaya: Surabaya

Intelektual Club, 2010.

Sutanto Windura, B. L. I. Mind Map

Langkah Demi Langkah. Elex

Media Komputindo, 2013.

Tim Satuasa. Buku Pintar

Mentoring(Smart, Fun dan Syar'i

Panduan Pembinaan Karakter

Pelajar). Jakarta: Yayasan Tunas

Bangsa Indonesia, 2016.

Yusuf, Muhammad. Memikat Siswa Sejak

Menit Pertama. Sidoarjo: MAKS,

2011. 